\title{
METHODS FOR DETERMINATION OF DEFORMATIONS WITH THE USE OF DIGITAL IMAGE CORRELATION TECHNOLOGIES
}

\author{
${ }^{1}$ Department of Highways and Bridges, \\ ${ }^{2}$ Department of Building Constructions and Bridges, \\ Lviv Polytechnic National University \\ yaroslav.z.blikharskyy@lpnu.ua
}

(C) Blikharskyy Y., Kopiika N., 2021

In order to obtain reliable information about the stress-strain state of the structure, subjected to loading, it is necessary to determine deformations' distribution. In some cases, it is almost impossible to assess stress-strain state with the traditional approaches. However, the DIC methods provide reliable information about the fields of displacement and deformation almost without limitations. Such approaches are rather effective for determination of the stress-strain state on smooth surfaces and in zones with stress concentrators. The DIC method is based on the comparison of the intensity of speckle pictures` distribution of optically rough surfaces. The combination of the intensities of correlation peaks with the corresponding calculation algorithms at the subpixel level makes it possible to obtain high measurement accuracy with simpler hardware compared to electronic interferometry technologies. The main purpose of this work is the detailed analysis of techniques and methods for determination of deformations with the use of digital image correlation. The article includes detailed review of existing studies of this topic and description of main principles for analytical computation of the optical data.

Keywords: deformations, digital image correlation, stress-strain state, information model.

\section{Introduction}

The practice of operation of reinforced concrete structures shows that the limit state in such structures is usually achieved in localized zones. This could be caused by many factors, both constructive and technological. In particular, the presence of welds in reinforced concrete structural elements changes the stress-strain state in such sections and affects the durability and load-bearing capacity. After long-term exploitation of reinforced concrete structural elements, the concentration of stresses and strains is localized in such places, which could become the reason of irreversible processes. If the real stress-strain state of such constructions is determined on the basis of classical criteria, it is rather hard to obtain reliable information. In such cases, the load-bearing capacity of structural elements should be analyzed on the basis of developed criteria and invariant physical and mechanical characteristics of materials by which the actual strength and durability could be established.

Inhomogeneity of stress-strain state along the length of the reinforced concrete beam could be confirmed by the formation of cracks in the concrete. Such specifics could be explained by different values of the ultimate strains of concrete and reinforcement along the length and localization of deformations in places of high concentration.

In recent scientific studies of strength and elastic-plastic deformation of metallic materials standard force methods are usually combined with the technologies of speckle metrology (Sutton et al, 1983; Sjodahl, 1998; Yamaguchi, 2003; Sjodahl, 2001). In particular, perspective concept is to measure the displacements to determine the deformation in the local volume, where the stress-strain state is almost the same. The method of digital image correlation (DIC) is based on the comparison of the intensity of 
speckle pictures` distribution of optically rough surfaces. It is important to note, that such method takes into account information only about the optical field intensity and does not take into account the phase component. However, the combination of the intensities of correlation peaks with the corresponding calculation algorithms at the subpixel level makes it possible to obtain high measurement accuracy with simpler hardware compared to electronic interferometry technologies (Jones, 1989; Greivenkamp,1992; Rastogi, 2001).

\section{Review of scientific sources and publications}

Technologies with the use of digital image correlation have been widely studied in the number of recent studies (Majumder et al, 2020; Chen et al, 2017; Lee et al, 2019) as an optical method, which enables to analyze different stress-strain states with the use of mathematical correlation. Cintrón et al (Cintrón et al, 2008) describe in their research main principles of the algorithm, which includes capturing of images during the deformation of the structure with the use of digital camera. After that, the researcher compares the "reference" image. taken before the loading began with deformed" images, which correspond to different load stages. Each of the images would contain the dot pattern with specific parameters, On the basis of dots` displacements, the deformations could be assessed. In most of recent studies researchers recommend to conduct such analysis with the use of specialized software, for example VIC-2D (Correlated Solutions Company, (VIC-2D. Reference Manual, 2009) and ARAMIS (GOM Company) (ARAMIS Manual).

Carter et al admit, that methods, which use DIC are rather flexible and could be used for wide range of applications. Authors (Carter et al, 2015; Zappa et al, 2017) also noted that DIC technologies could be used for different dynamic tests, thermomechanical analysis, as well as for the analysis of fatigue stresses and cracks in the metal, etc. In the article (Blikharskyy et al, 2020) it is emphasized, that technologies, which use digital image correlation are the most appropriate approach, combining high accuracy of theoretical results and possibility to input in the model experimental data. Such analysis enables the researcher to obtain the full-range stress-strain image of the studied object.

The number of works (Cintrón et al, 2008; Chen et al, 2017; Mazzoleni et al, 2015; Chen et al, 2015; Kramer et al, 2017; Bomarito, Ruggles et al, 2017; Bomarito, Hochhalter et al, 2017; Cannon et al, 2017) were dedicated to study of possible ways to optimize the dot image. According to data of Cintrón et al (Cintrón et al, 2008), the appropriate dot pattern, which would provide the highest reliability of results should contain specific ratio of dots of different sizes. Moreover, the optimal ratio depends on the pixel density, which is, namely, the number of pixels per point $\mathrm{p}$ (10,20 and 30 pixels for small, medium and large size) (Cintrón et al, 2008). The same issue was discussed in studies of (Chen et al, 2017; Mazzoleni et al, 2015; Chen et al, 2015; Kramer et al, 2017; Bomarito, Ruggles et al, 2017; Bomarito, Hochhalter et al, 2017) in detail. In particular, in work (Chen et al, 2017) the emphasis is made on form and size of points. Thus, it is recommended to use the dots with different radius, scilicet, the same as was noted by Cintrón et al (Cintrón et al, 2008). According to results of (Kramer et al, 2017; Bomarito, Ruggles et al, 2017; Bomarito, Hochhalter et al, 2017), the simplest way to obtain the optimal pattern is to conduct iterative automatic modelling with use the specialized equipment and software. Namely, the efficiency of the results could be increased up to $25 \%$, if sufficient attention is paid to such pattern parameters as optimal contrast, size and density, which could be described by specific numerical indicator of the distribution quality (Kramer et al, 2017; Bomarito, Ruggles et al, 2017; Bomarito, Hochhalter et al, 2017). This aspect is discussed in (Bomarito, Hochhalter et al, 2017), where the author proposes to use newly developed Micro Speckle Stamping technology, specific features of which are that it uses highly contrast electrical and optical materials. Therefore, no traces are left between points and this technique could be used even for large areas and surfaces of complex configuration (Bomarito, Hochhalter et al, 2017). The complete diagrams of stressstrain state of structural elements are produced by specific software on the basis of relative displacements of points $\varepsilon_{x}, \varepsilon_{y}$ (Bomarito, Hochhalter et al, 2017; Saldaña et al, 2015; Lee et al, 2019). It is important to 
note studies (Jones et al, 2017; Segouin et al, 2017; Denys et al, 2017; Giordano, 2020), where the complete information model of the studied surface was obtained with the use of digital image correlation techniques. In addition, as was confirmed by authors (Denys et al, 2017; Poozesh, 2017; Rossi, 2018; Yasmeen, 2017; Buljac et al, 2020; Kumar, Hassebrook,1990), DIC methods is the only possible way nowadays to obtain the full-range three-dimensional informational model of the structural element, which is highly promising advantage for further scientific use.

\section{The aims and objectives of the study}

The main purpose of this work is the detailed analysis of techniques and methods for determination of deformations with the use of digital image correlation. The article includes detailed review of existing studies of this topic and description of main principles for analytical computation of the optical data.

\section{Main principles of determination of deformations with the use of DIC techniques}

During the deformation of the structural element on its surface and in the deeper layers of the material in the zones of singularities, various surface inhomogeneities appear various gaps in the phase field of the speckle image. It is almost impossible to quantify the stress zones of the material surface by speckle interferometry methods, because the phase component is not taken into account in the correlation fragment in speckle patterns. However, almost in all cases the fields of displacement and deformation could be assessed with the use of the DIC methods. Therefore, such approaches are rather effective for determination of the stress-strain state on smooth surfaces and in zones with stress concentrators.

There is the number of information technologies that are based on the registration of displacements in two coordinates. The most well-known is digital image correlation based on laser surface illumination (Sutton et al, 1983; Yamaguchi, 2003; Schreier et al, 2000), the method for digital speckle-displacement measurement in which incoherent surface illumination is used (Chen, Chiang, 1990; Chen, Chiang, 1993; Chen et al, 1993) and electronic speckle photography (Sjodahl, 1998; Sjodahl, 2001). The main idea of all these methods is to perform certain operations on speckle patterns of optically rough surface. Operations are conducted in the same sequence, taking into account some differences.

DIC technology algorithm includes the following stages. First, the studied surface is illuminated with coherent (laser) light or incoherent radiation, after which the speckle image of this surface is recorded by matrix detector in the form of a CCD-matrix or CMOS sensor with the use of complementary metal oxide semi-conductor in digital camera or video camera.

The initial stage of the DIC method includes the registration of the speckle pattern of the undeformed surface, which could be described by the function $r(x, y)$ and $r_{m, n}$. Also, the speckle pattern of the deformed surface is registered (Fig. 1).
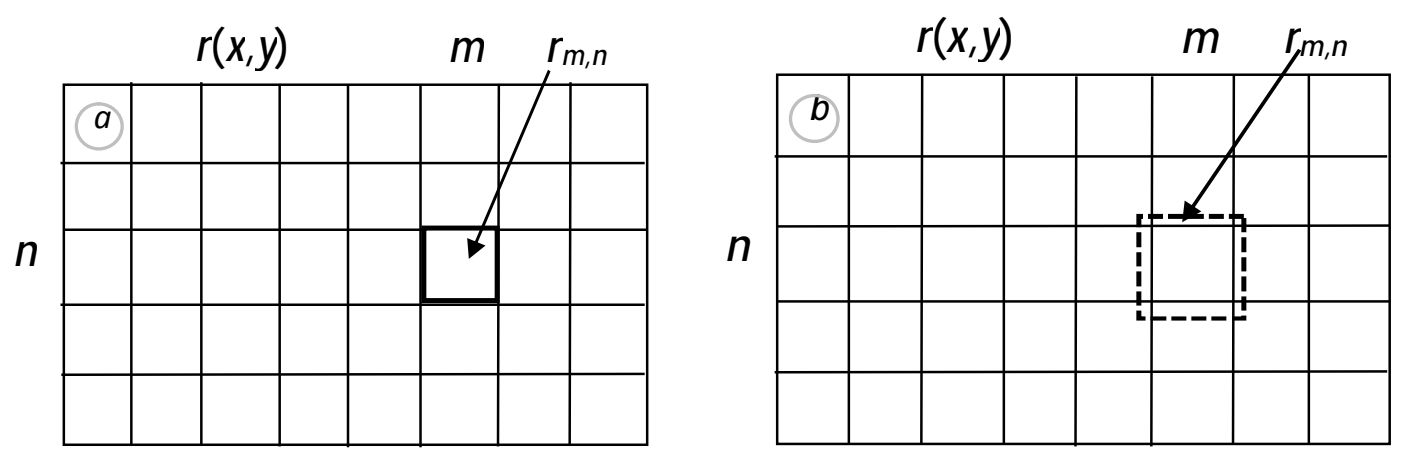

Fig. 1. Representation of the image $r(x, y)$ into square fragments $r_{m, n}(x, y)$ and their selection without covering of the adjacent fragments $(a)$ and $(b)$. 
Images 1 and 2, registered with a video camera are stored in personal computer in digital form with the use of appropriate software. These images are further described by the functions $r(x, y)$ and $S(x, y)$. Subsequently, digital images 1 and 2 are decomposed into two $\mathrm{M} \times \mathrm{N}$ matrices of rectangular fragments $Z_{-}(m, n)(x, y)$ and $S_{m, n}(x, y)$ of the same size, where $m=1 \ldots M ; n=1 \ldots N$.

Fragments could be with or without covering of the adjacent fragments. The most often are used the fragments of square shape of $8 \times 8,16 \times 16,32 \times 32,64 \times 64$ pixels.

Next is determined the movement of each fragment $S_{m, n}(x, y)$ (image 2) relative to the fragment $r_{m, n}(x, y)$ (image 1) with the same numbering as the fragment $S_{m, n}(x, y)$. The fragments $S_{m, n}(x, y)$ are considered as a part of the fragment $r_{m, n}(x, y)$ distorted by interference, which is shifted relative to its initial position by a distance, which could be calculated as:

$$
\Delta l=\sqrt{(\Delta x)^{2}+(\Delta y)^{2}} .
$$

It is known that in Figure 2 could be found such a fragment $S_{m, n}(x, y)$ which corresponds to the distorted fragment $r_{m, n}(x, y)$.
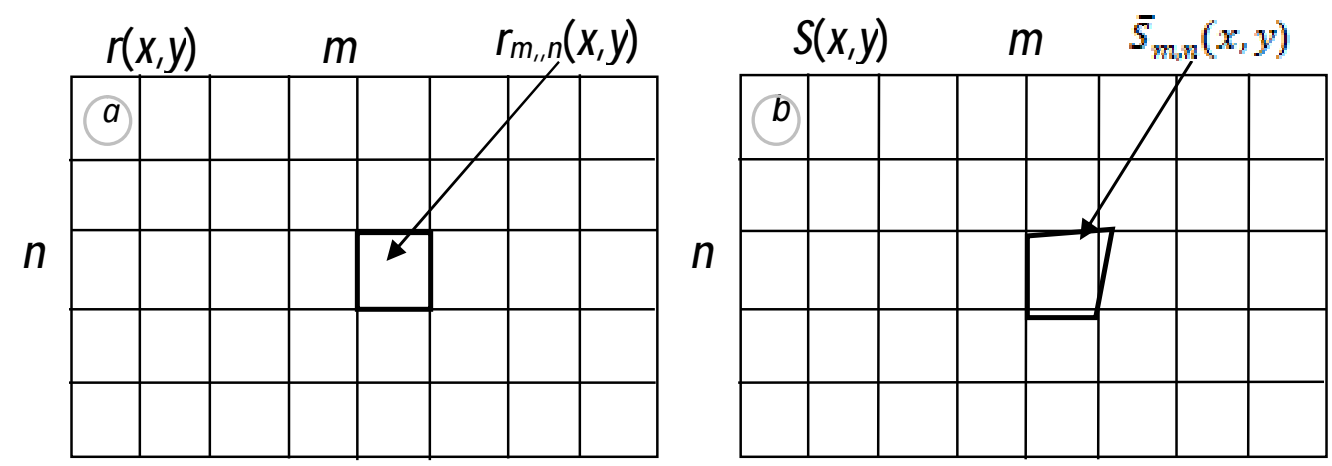

Fig. 2. Determination of the fragment $r_{m, n}(x, y)(a)$ and its transformed by noises and interference form $S_{m, n}(x, y)(b)$

Analytical equation for determination of $S_{m, n}(x, y)$ is the following:

$$
S_{m, n}(x, y)=\bar{r}_{m, n}(x+\Delta x, y+\Delta y)=r_{m, n}(x+\Delta x, y+\Delta y) \cdot m_{m, n}(x, y)+n_{m, n}(x, y),
$$

where $m_{m, n}(x, y)$ - multiplicative noise; $n_{m, n}(x, y)$-additive noise

In order to determine the value of displacement $\Delta l$ for each fragment $S_{m, n}(x, y)$ the cross-correlation technique could be used:

$$
\bar{C}_{m, n}(\Delta x, \Delta y)=\int_{-\infty}^{+\infty} \int_{-\infty}^{+\infty} r_{m, n}(x, y) \cdot r_{m, n}(x+\Delta x, y+\Delta y)+\Delta y d x d y
$$

This forms a cross-correlation peak, the maximum of which corresponds to the position of the fragment $Z_{\min }(x, y)$, moved from its initial position. Thus, the cross-correlation of two fragments is conducted by following simplified scheme:

$$
\begin{gathered}
r_{m, n}(x, y)=\bar{r}_{m, n}(x, y)+g_{m, n}(x, y), \\
S_{m, n}(x, y) r_{m, n}^{\prime}(x+\Delta x, y+\Delta y) \cdot m_{m, n}^{\prime}(x, y)+n_{m, n}^{\prime}(x, y)+f_{m, n}(x, y),
\end{gathered}
$$


where $\bar{r}_{m, n}(x, y)$-common part of fragments, $m_{m, n}(x, y), h_{m, n}(x, y)$-multiplicative and additive noises in the moved sub-fragment $r_{m, n}^{\prime}(x+\Delta x, y+\Delta y) ; g_{m, n}(x, y)$-part of fragment $r_{m, n}(x, y) ; f_{m, n}(x, y)$ - part of fragment $S_{m, n}(x, y)$ (Fig. 3).

Thus, the cross-correlation of functions $r_{m, n}(x, y), S_{m, n}(x, y)$ could be performed in the following way:

$$
C_{m i n}(\Delta x, \Delta y)=\int_{-\infty}^{+\infty} \int_{-\infty}^{+\infty} r_{m, n}(x, y) \cdot S_{m, n}^{*}(x+\Delta x, y+\Delta y)+\Delta y d x d y
$$

where symbol $*_{-}$identifies the complex conjugate function.

As a result, the maximum value of $\mathrm{m}, \mathrm{n}$-correlation peak is moved from its initial position on the distance:

$$
\Delta l_{m, n}=\sqrt{\left(\Delta x_{m, n}\right)^{2}+\left(\Delta y_{m, n}\right)^{2}} \text {. }
$$
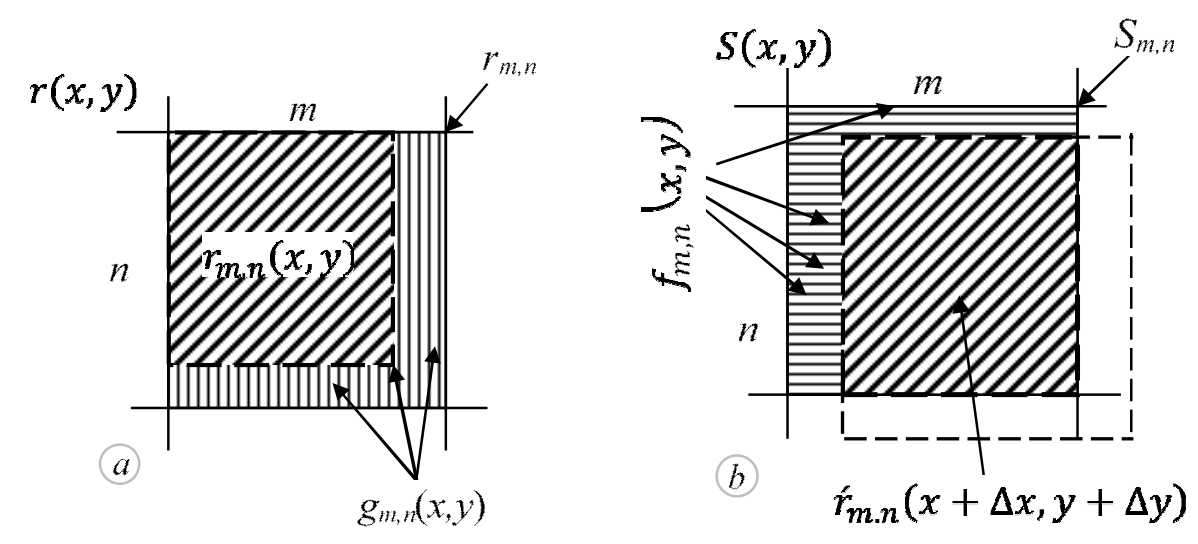

Fig. 3. Position of fragments and sub-fragments in speckle image $r(x y)(a), S(x, y)(b)$

This initial peak is due to autocorrelation of initial fragment $r_{m, n}(x, y)$. Therefore, distance $\Delta l$ corresponds to offset of fragment $S_{m, n}(x, y)$ from initial $r_{m, n}(x, y)$.

For digital calculations, the equation in discrete form can be rewritten as (Sjodahl, Benckert, 1993):

$$
C_{\text {min }}(k, l)=\sum_{i} \sum_{j} r_{m, n}(i, j) \cdot S_{m, n}^{*}(i+k, j+l),
$$

where $i=1 \ldots I, j=1 \ldots J-$ the readings for functions $r_{m, n}, S_{m, n}, k=1 \ldots K, l=1 \ldots L$ - readings for cross-correlation function $C_{m, n}$, respectively.

For practical purposes $C_{\min }(k, l)$ could be calculated with the use of simplified formula (Sjodahl, 1998; Sjodahl, Benckert, 1993):

$$
C_{m i n}(k, l)=F_{d}^{-1}\left[C_{m, n}(p, g)\right]=F_{d}^{-1}\left\{R_{m, n}(p, g)+S_{m, n}(p, g)\right\},
$$

where $R_{m, n}(p, g)=F_{d}\left\{r_{m, n}(i, j)\right\}, S_{m, n}(p, g)=F_{d}\left\{S_{m, n}(i, j)\right\}, F_{d}, F_{d}^{-1}$ - operators of direct and inverse discrete two-dimensional Fourier transformation, $p=1 \ldots P, q=1 \ldots Q$-readings of functions in Fourier area. Important to admit, that $I=J=K=L=P=Q$.

Formula (9) enables to calculate the peak displacement for integer number of pixels. Thus, it is possible to determine the position of the correlation peak with sub-pixel accuracy. 


\section{Yaroslav Blikharskyy, Nadiia Kopiika}

Using the Fourier shift theorem and formula (9) could be obtained the equation for the shifted function $\left\{C_{m, n}\right\}_{\text {shift }}$ for the certain readings`value as following (Sjodahl, 1994; Bracewell, 1986):

$$
C_{m, n}(k, l)\left(C_{m, n}\right)_{\text {shift }}=F_{d}^{-1}\left\{C_{m, n}(p, g) \exp \left[-\frac{2 \pi\left(a_{x} p+a_{y} g\right)}{P}\right]\right\},
$$

where $a_{x}, a_{y}$ - relative values of displacements.

$$
\begin{aligned}
& \Delta x=k+a_{x}, \\
& \Delta y=l+a_{y},
\end{aligned}
$$

The Sodal-Bankert algorithm can be used to calculate the peak displacement of the function $\left(C_{m, n}\right)_{\text {shift }}$ with subpixel accuracy.

According to studies (Chen et al, 1993; Vijaya, 1990) the accuracy could be increased with the use of fractional degree filter, so that the correlation peak is narrowed. The initial correlation signal $C_{m, n}(k, l)$ could be calculated with the use of formula:

$$
C_{m, n}(k, l)=F_{d}^{-1}\left\{\frac{\left[R_{m, n(p, g)} S_{m, n(p, g)}^{*}\right]}{\left[R_{m, n(p, g)} S_{m, n(p, g)}^{*}\right]^{\frac{t}{2}}}\right\},
$$

where $\mathrm{t}$ - the filter parameter, which could be equal only to real values.

Taken into account, that the filter could decrease the output signal by amplifying high-frequency noises, the reliability of determining the position of the peak is reduced. To reduce the impact authors in (Sjodahl, 1994) use additionally bi-parabolic interpolation algorithm after filtering.

Next, the matrix of correlation peaks is formulated (see Fig. 4).

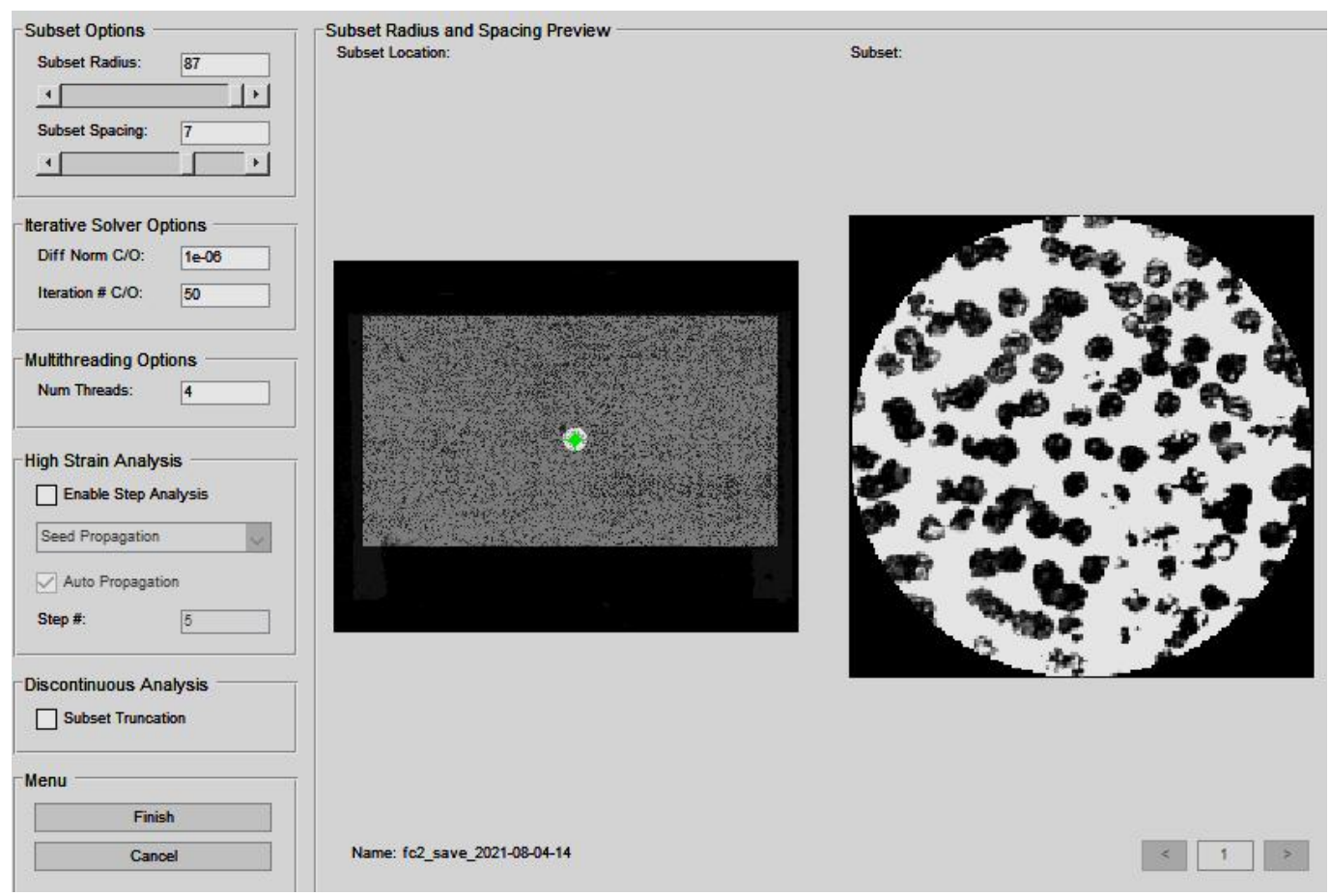

Fig. 4. Matrix of correlation peaks, obtained by fragmentary cross-correlation of images 
Displacements of peaks could be recorded as the matrix of displacement vectors:

$$
\Delta \bar{l}_{m, n}=(\Delta x) \cdot \bar{i}+(\Delta y) \cdot \bar{j} .
$$

or as the matrix of deformations vectors:

$$
\Delta \bar{\varepsilon}_{m, n}=\frac{\Delta x_{m, n}}{b_{x}} \cdot \bar{i}+\frac{\Delta y_{m, n}}{b_{y}} \cdot \bar{j} .
$$

where $b_{x}, b_{y}$ are the minimum bases for deformations determination along the axes $\mathrm{x}$ and $\mathrm{y}$, which are equal to distances between centers of adjacent fragments $r_{m, n}(x, y)$.

In order to simplify the calculations for practical purposes could be assumed that $b_{x}=b_{y}$, so that matrices of vectors of displacements and deformations can be considered as two-dimensional fields of speckle pictures of displacements or deformations taking into account linear increase in registration systems.

\section{Conclusions}

Based on the conducted thorough analysis, it can be argued that methods using digital image correlation are rather promising innovative techniques which could be used for wide range of applications. Among perspective ways of their usage are diagnosis, monitoring and control of the condition of building structures and materials. It is important to note, that use of DIC methods for determination of deformations require usage of complex analytical approach with iterative calculation algorithms. Also, accuracy and efficiency could be increased if specialized software is used for this purpose. In general, digital image correlation is the only approach, which allows to obtain the full-range information field and analyze stress-strain state of the structure, subjected to different levels of loading.

\section{References}

Blikharskyy Ya. Z. \& Kopiika N. S. Digital image correlation method for analysis of reinforced concrete structures (2020). Bulletin of Odessa State Academy of Civil Engineering and Architecture, 2020, 78, 27-33 doi: 10.31650/2415-377X-2020-78-27-33

Bomarito, G. F., Hochhalter, J. D., Ruggles, T. J., \& Cannon, A. H. (2017). Increasing accuracy and precision of digital image correlation through pattern optimization. Optics and Lasers in Engineering, 91, 73-85. doi: 10.1016/j.optlaseng.2016.11.005

Bomarito, G. F., Ruggles, T. J., Hochhalter, J. D., \& Cannon, A. H. (2017). Investigation of optimal digital image correlation patterns for deformation measurement. In International Digital Imaging Correlation Society (pp. 217-218). Springer, Cham. doi: 10.1007/978-3-319-51439-0_51.

Bracewell, R. N., \& Bracewell, R. N. (1986). The Fourier transform and its applications (Vol. 31999, pp. 267-272). New York: McGraw-Hill.

Buljac, A., Jailin, C., Mendoza, A., Neggers, J., Taillandier-Thomas, T., Bouterf, A., \& Roux, S. (2020). Digital volume correlation: progress and challenges. In Advancements in Optical Methods \& Digital Image Correlation in Experimental Mechanics, Volume 3 (pp. 113-115). Springer, Cham. doi: 10.1007/978-3-030-30009-8_17

Cannon, A. H., Hochhalter, J. D., Bomarito, G. F., \& Ruggles, T. (2017). Micro speckle stamping: High contrast, no basecoat, repeatable, well-adhered. In International Digital Imaging Correlation Society (pp. 141-143). Springer, Cham. doi: 10.1007/978-3-319-51439-0_34

Carter, J. L., Uchic, M. D., \& Mills, M. J. (2015). Impact of speckle pattern parameters on DIC strain resolution calculated from in-situ SEM experiments. In Fracture, Fatigue, Failure, and Damage Evolution, Volume 5 (pp. 119-126). Springer, Cham. doi: 10.1007/978-3-319-06977-7_16

Chen D. J., Chiang F. P. Computer speckle interferometry // Proc. Of Intern. Confer. On Hologram interferometry and Speckle Metrology. - Baltimore: Society for Experimental Mechanics, 1990. - P.49-58.

Chen, D. J., \& Chiang, F. P. (1993). Computer-aided speckle interferometry using spectral amplitude fringes. Applied Optics, 32(2), 225-236. doi: 10.1364/AO.32.000225 
Chen, D. J., Chiang, F. P., Tan, Y. S., \& Don, H. S. (1993). Digital speckle-displacement measurement using a complex spectrum method. Applied optics, 32(11), 1839-1849. doi: doi.org/10.1364/AO.32.001839

Chen, Z., Quan, C., Zhu, F., \& He, X. (2015). A method to transfer speckle patterns for digital image correlation. Measurement science and technology, 26(9), 095201. doi: 10.1088/0957-0233/26/9/095201

Chen, Z., Xu, X., Wu, J., \& He, X. (2017). Optimization of speckle pattern for digital image correlation. In International Digital Imaging Correlation Society (pp. 29-31). Springer, Cham. doi: 10.1007/978-3-319-51439-0_7

Cintrón, R., \& Saouma, V. (2008). Strain measurements with the digital image correlation system Vic2D. System, 106, $2 D$.

Denys, K., Coppieters, S., \& Debruyne, D. (2017). Identification of a 3D Anisotropic Yield Surface Using a Multi-DIC Setup. In International Digital Imaging Correlation Society (pp. 101-104). Springer, Cham.. doi: 10.1007/978-3-319-51439-0_24

Greivenkamp, J. E. (1992). Phase shifting interferometers. Optical shop testing, 501-598.

Jones, E. M. C., Carroll, J. D., Karlson, K. N., Kramer, S. L. B., Lehoucq, R. B., Reu, P. L., \& Turner, D. Z. (2017). Combining Full-Field Measurements and Inverse Techniques for Smart Material Testing. In International Digital Imaging Correlation Society (pp. 37-39). Springer, Cham. doi: 10.1007/978-3-319-51439-0_9

Jones, R., Wykes, C., \& Wykes, J. (1989). Holographic and speckle interferometry (No. 6). Cambridge university press.

Kramer, S., Reu, P., \& Bonk, S. (2017). A speckle patterning study for laboratory-scale DIC experiments. In International Digital Imaging Correlation Society (pp. 33-35). Springer, Cham. doi: 10.1007/978-3-319-51439-0_8

Kumar, B. V., \& Hassebrook, L. (1990). Performance measures for correlation filters. Applied optics, 29(20), 2997-3006.doi: 10.1364/AO.29.002997

Lee, J., Kim, E. J., Gwon, S., Cho, S., \& Sim, S. H. (2019). Uniaxial static stress estimation for concrete structures using digital image correlation. Sensors, 19(2), 319.doi: 10.3390/s19020319

Majumder, S., Gupta, S., \& Dubey, S. (2020). Spectral imaging using compressive sensing-based singlepixel modality. Electronics Letters, 56(19), 1013-1016. doi: 10.1049/el.2020.0757

Mazzoleni, P., Zappa, E., Matta, F., \& Sutton, M. A. (2015). Thermo-mechanical toner transfer for highquality digital image correlation speckle patterns. Optics and Lasers in Engineering, 75, 72-80. doi: 10.1016/ j.optlaseng.2015.06.009

Optical 3D Deformation Analysis. ARAMIS Manual (GOM Company) Retrieved from: http://www.henindo.co.id/home/ARAMIS_EN_RevB.pdf

Poozesh, P., Sarrafi, A., Niezrecki, C., Mao, Z., \& Avitabile, P. (2017). Extracting high frequency operating shapes from 3D DIC measurements and phased-based motion magnified images. In International Digital Imaging Correlation Society (pp. 81-83). Springer, Cham. doi: 10.1007/978-3-319-51439-0_20.

Rossi, M., Cortese, L., Genovese, K., Lattanzi, A., Nalli, F., \& Pierron, F. (2018). Evaluation of volume deformation from surface DIC measurement. Experimental Mechanics, 58(7), 1181-1194. doi: 10.1007/s11340018-0409-0

Saldaña, H.A., Márquez Aguilar, P.A. \& Molina, O.A. (2015) Concrete Stress-Strain Characterization by Digital Image Correlation, Journal of Applied Mechanical Engineering, 4 (189), 6,1-5. doi: 10.4172/21689873.1000189

Schreier, H. W., Braasch, J. R., \& Sutton, M. A. (2000). Systematic errors in digital image correlation caused by intensity interpolation. Optical engineering, 39(11), 2915-2921. doi: 10.1117/1.1314593

Segouin, V., Domenjoud, M., Bernard, Y., \& Daniel, L. (2017). Development of a 2D DIC experimental tool for piezoelectric strains measurements. In International Digital Imaging Correlation Society (pp. 45-50). Springer, Cham. doi: 10.1007/978-3-319-51439-0_11.

Sjodahl M. (2001) Digital speckle pattern interferometry and related techniques. Digital Speckle Photography/ Ed. By P. K. Rastogi.- Chichester; John Wiley and Sons. - P. 289-336.

Sjödahl, M. (1994). Electronic speckle photography: increased accuracy by nonintegral pixel shifting. Applied Optics, 33(28), 6667-6673. doi: 10.1364/AO.33.006667

Sjödahl, M. (1998). Some recent advances in electronic speckle photography. Optics and lasers in engineering, 29(2-3), 125-144. doi: 10.1016/S0143-8166(97)00081-X.

Sjödahl, M., \& Benckert, L. R. (1993). Electronic speckle photography: analysis of an algorithm giving the displacement with subpixel accuracy. Applied Optics, 32(13), 2278-2284.doi: doi.org/10.1364/AO.32.002278 


\section{Methods for determination of deformations with the use of Digital Image Correlation technologies}

Sutton, M. A., Wolters, W. J., Peters, W. H., Ranson, W. F., \& McNeill, S. R. (1983). Determination of displacements using an improved digital correlation method. Image and vision computing, 1(3), 133-139. doi: 10.1016/0262-8856(83)90064-1

VIC-2D. Refrence Manual. Correlated Solutions. Retrieved from: http://www.correlatedsolutions.com/ installs/Vic-2D-2009-Manual.pdf

Yamaguchi, I. (2003, May). Fundamentals and applications of speckle. In Speckle Metrology 2003 (Vol. 4933, pp. 1-8). International Society for Optics and Photonics. doi: 10.1117/12.516567

Yasmeen, F., Rajan, S., Sutton, M. A., \& Schreier, H. W. (2017). Experimental study of measurement errors in 3D-DIC due to out-of-plane specimen rotation. In International Digital Imaging Correlation Society (pp. 211-215). Springer, Cham. doi: 10.1007/978-3-319-51439-0_50

Zappa, E., \& Hasheminejad, N. (2017). Digital image correlation technique in dynamic applications on deformable targets. Experimental Techniques, 41(4), 377-387. doi: 10.1007/s40799-017-0184-3

Я. З. Бліхарський ${ }^{1}$, Н. С. Копійка ${ }^{2}$ Національний університет "Львівська політехніка",

${ }^{1}$ кафедра автомобільних доріг та мостів,

2 кафедра будівельних конструкцій і мостів

\section{МЕТОДИ ВИЗНАЧЕННЯ ДЕФОРМАЦЙ З ВИКОРИСТАННЯМ ЦИФРОВОЇ КОРЕЛЯЦЇ̈ ЗОБРАЖЕНЬ}

(C) Бліхарський Я. 3., Копійка Н. С., 2021

Останнім часом особливо актуальним стало питання достовірної оцінки фактичного стану будівельних конструкцій, що містяться під навантаженням i, відповідно, прийняття оптимальних проектних рішень з реконструкції та підсилення. Для отримання достовірної інформації про напружено-деформований стан конструкції, що зазнає навантаження, необхідно визначити розподіл деформацій. У деяких випадках оцінити напружено-деформований стан традиційними підходами практично неможливо. Однак методи цифрової кореляції зображень забезпечують достовірну інформацію про поля переміщень та деформації і можна застосовувати майже без обмежень. Такі підходи досить ефективні для визначення напружено-деформованого стану на гладких поверхнях та в зонах 3 концентраторами напружень. Метод цифрової кореляції зображень заснований на порівнянні інтенсивності розподілу спекл-картинок оптично шорстких поверхонь. Поєднання інтенсивності кореляційних піків з відповідними алгоритмами розрахунків на рівні субпікселів дає змогу отримати високу точність вимірювання за допомогою простішого обладнання порівняно з технологіями електронної інтерферометрії. Основною метою цієї роботи є детальний аналіз прийомів і методів визначення деформацій із застосуванням цифрової кореляції зображення. Стаття містить детальний огляд наявних досліджень цієї теми та опис основних принципів аналітичного обчислення оптичних даних. На основі проведеного ретельного аналізу можна стверджувати, що методи ЦКЗ є досить перспективними інноваційними технологіями, які можна використовувати для широкого спектру застосувань. Серед перспективних напрямків їх використання - діагностика, моніторинг та контроль стану будівельних конструкцій та матеріалів. Важливо зазначити, що використання методів ЦКЗ для визначення деформацій потребує використання комплексного аналітичного підходу з ітераційними алгоритмами розрахунків. Крім того, точність та ефективність можна збільшити, якщо для цього використовують спеціалізоване програмне забезпечення. Загалом кореляція цифрових зображень - це єдиний підхід, який дає змогу отримати повну інформаційну модель конструкції, що зазнає різного рівня навантаження.

Ключові слова: деформації, цифрова кореляція зображень, напружено-деформований стан, інформаційна модель конструкції. 